\title{
Early Cretaceous striate tricolpate pollen from the Borehole Mersa Matruh 1, North West Desert, Egypt
}

\author{
JAMES H. J. PENNY \\ The Haberdashers' Aske's School, Butterfly Lane, \\ Elstree, Borehamwood, Hertfordshire WD6 3AF
}

\begin{abstract}
Striate tricolpate pollen has been recovered from Early Cretaceous samples of the borehole Mersa Matruh 1 in the N.W. Desert of Egypt. Scanning Electron Microscope (SEM) study has revealed fine details of their exine scupture, on the basis of which four new taxa, STRIOTRI-OVAL, STRIOTRI-SMOOTHMUR, STRIOTRI-SEGMUR and STRIORET-SMOOTH, are distinguished. The stratigraphic ranges of these are discussed and they are compared with other published species. They are among the oldest striate tricolpate pollen yet described, appearing in sediments of Early Aptian age, slightly predating the first reliable records of reticulate tricolpates in the sequence studied. The lack of earlier reticulate grains is attributed to possible sample failure. There is evidence that the true first appearance of tricoplate pollen in Egypt may be late Barrenian.
\end{abstract}

\section{INTRODUCTION}

Striate tricolpate pollen was first recorded in sediments of Tertiary age (e.g. Van der Hammen, 1956; Krutzsch, 1959; Rouse, 1962). Several genera were erected to accommodate these observations, including Striatopollis Krutzsch, 1959, Striopollenites Rouse, 1962 (the junior synonym of Striatopollis; Potonie, 1966, p. 164 and Striatricolpites Van der Hammen, 1956 which is invalid, see Potonie, 1970. Some striates have also been accommodated in the genus Retimonocolpites (Pierce) Van der Hammen, 1956.

More recently striates have been recorded from Cretaceous sediments of Albian to Cenomanian age (Norris, 1967; Hedlund \& Norris, 1968; Playford, 1971; Singh, 1971; Dettmann, 1973; Laing, 1975; Doyle \& Robins, 1977) and possibly as early as Aptian (Doyle et al., 1977; Gubeli et al. 1985).

The purpose of this paper is to publish four new forms which have been recovered from Aptian sediments of the borehole Mersa Matruh 1. This is located in the N.W. Desert of Egypt (Text fig. 1). The new forms are described from SEM details and are not separable with light microscopy. They have been compared with published forms, two of which also have SEM details available (Dettmann, 1973; Laing, 1975). Several interesting similarities are revealed that may indicate a close relationship between the Egyptian pollen and that known elsewhere.

The palynoflora associated with these striates is of mainly terrestrial origin and includes pollen and spore assemblages which are typical of the pre-Albian West African-South American (WASA) and Middle Cretaceous African-South American (ASA) microfloral provinces of Herngreen and Chlonova (1981). This indicates that the contemporary flora was probably growing in a warm subtropical, possibly seasonally dry, climate.

\section{GEOLOGICAL BACKGROUND}

The early Cretaceous sediments which are penetrated by Mersa Matruh 1 show a progressive stratigraphic change from fully marine to marginal deltaic conditions (Text fig. 2).

The oldest part of the sequence studied contains a marine palynoflora, with many cosmopolitan dinocysts, acritarchs and fragments of the organic linings of foraminiferid tests.

The rocks of this age form part of the Matruh Shale, a very thick unit of dark brown to dark grey, slightly indurated fissile shales with occasional sandy and calcareous interbeds. The sediments appear to have been deposited rapidly in a synsedimentary graben or pull-apart basin. A progressive change to more marginal marine conditions is indicated by the gradual reduction in the dinocyst representation, associated with the appearance of the abundant terrestriallyderived palynoflora. This is present in the upper part of this unit and in the overlying sediments (Text fig. 2).

The Matruh Shale is overlain conformably by the Kharita Member of the Burg el Arab Formation, a unit of fine to coarse quartzose sandstone interbedded with shales and carbonates. Further indication of progressively shallower conditions is provided by the gradual increase in the sand and silt content of the shales in this unit and by the greater frequency of sandy interbeds.

\section{METHODS}

The samples studied were mainly cores, but some cutting samples (marked $*$ in the text) were also examined. In most cases the sub-samples processed 


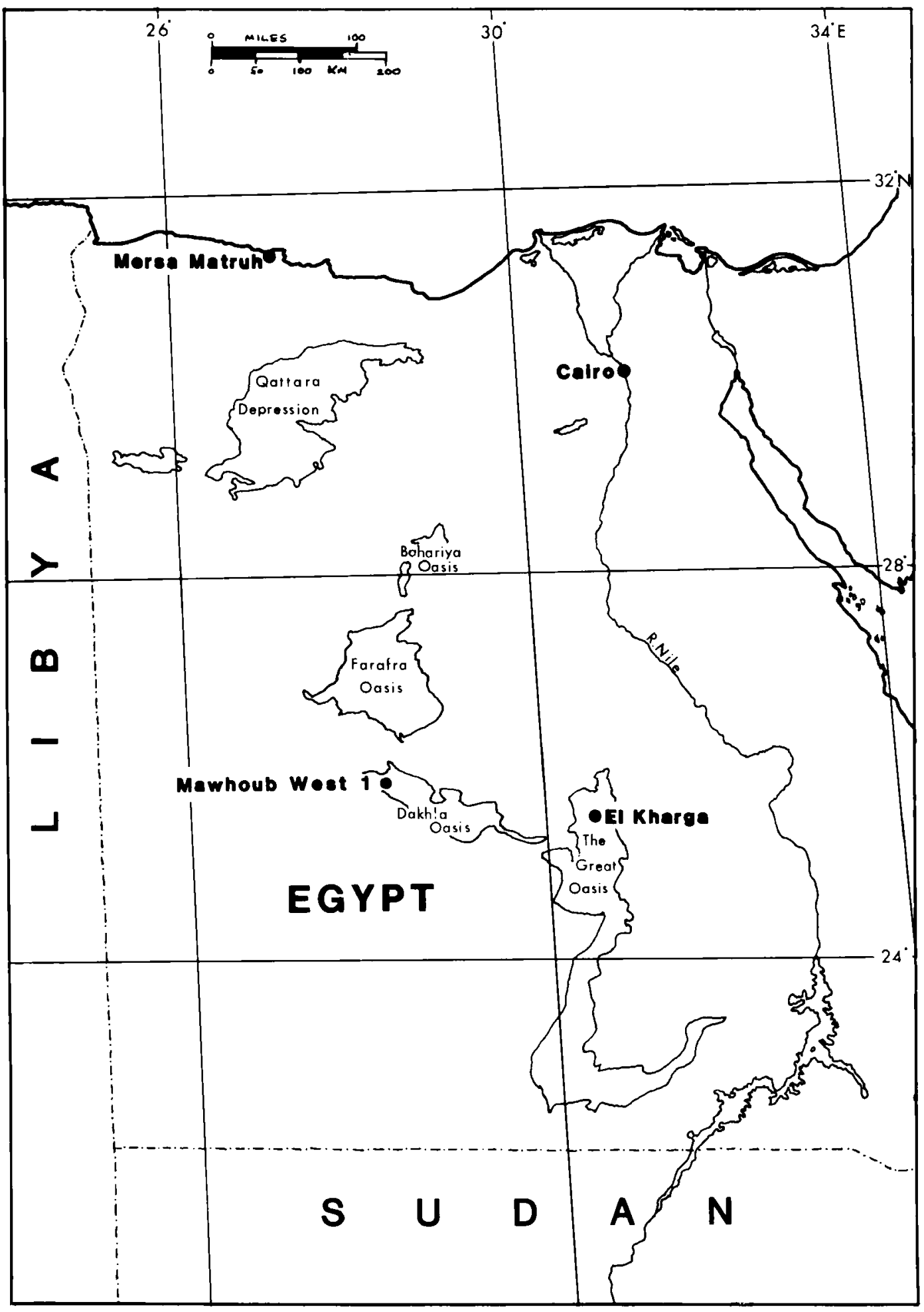

Fig. 1. A sketch map to show the location of the borehole Mersa Matruh 1 . 

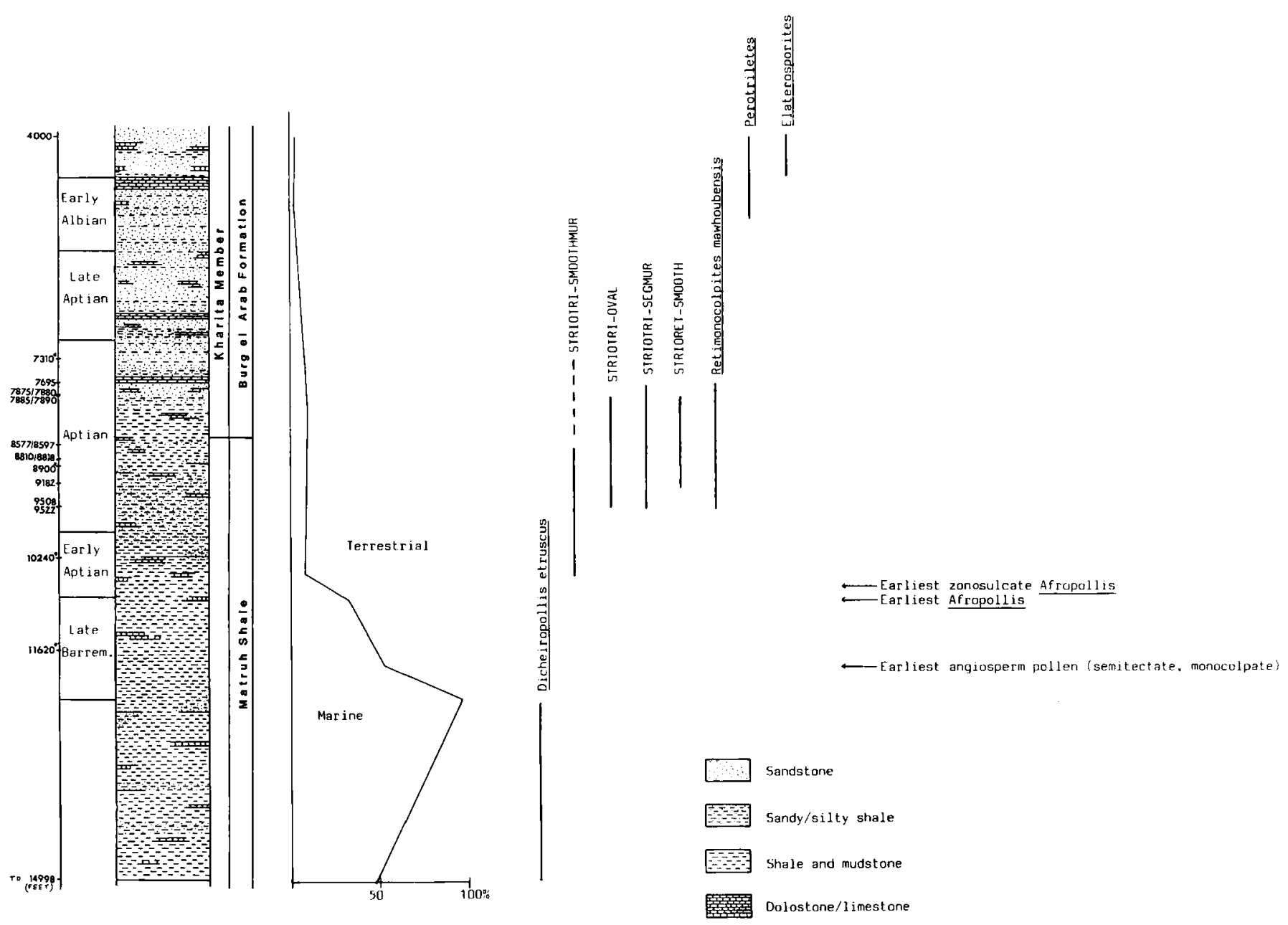

Stratigraphic log of Mersa Matruh 1 showing (left) the changes in lithology and marine: terrestrial palynomorph ratio and (right) the ranges of the pollen discussed in the paper. Some other stratigraphically-relevant ranges and first appearances are also shown.

were of limited quantity, usually two to ten grams, because of the small size of the original samples.

Standard palynological extraction methods were used for sample preparation, involving $\mathrm{HCl}, \mathrm{HF}$, centrifuging and the use of zinc bromide (S.G. $=2.0$ ) as a heavy liquid.

Unwanted organic debris was removed by treatment with concentrated nitric acid for periods of between five and ten minutes, followed by brief alkali clearance using 5\% ammonium hydroxide solution. Where particularly large quantities of organic debris were present in a sample, a saturated solution of chromium trioxide in concentrated nitric acid was found to be a more suitable oxidant; treatments with this solution were limited to 1-3 minutes. Some samples were also improved by cautious short centrifuge treatment to remove very fine debris.

Strew mount preparations were made of the organic residues on stubs equipped with Mark 3 Cambridge Geology SEM grids (cf. Hughes et al., 1979). After coating with gold the stubs were traversed systematically and a record made of the palynomorphs encountered. Specimens were recorded by photography on $70 \mathrm{~mm}$ Ilford FP4 film and may be relocated on the stubs by their grid coordinates.

All material relating to this study is deposited in the Department of Earth Sciences, Cambridge University, U.K.

\section{SYSTEMATIC DESCRIPTIONS}

Records were made using the biorecord/comparison record system of Hughes (1976) within the format suggested by Hughes (1986). This will enable future workers to recover individual records which can then be assessed on their own merit. The records are stored on floppy discs for easy transmission. 


\begin{tabular}{|c|c|}
\hline \multicolumn{2}{|r|}{ REFERENCE TAXON DESCRIPTION } \\
\hline Group of organisms & $\mathrm{J}$ Tricolpate pollen \\
\hline Sequence age & G Mesozolc / Cretaceous / Late Aptian \\
\hline Originator & A Penny,J.H.J. Cambridge University, U.K. ' \\
\hline Origination date & B 1987, July 20, fourteen 10. \\
\hline Taxon name & K Biorecord STRIOTRI-SEGMUR \\
\hline $\begin{array}{l}\text { Description } \\
\text { Prolate trico } \\
\text { (12.41) } 20.6 \text { um } \\
\text { narrower grains } \\
\text { expanded grains } \\
\text { Muri rounded in } \\
(0.2) 0.23 \text { um, } \\
\text { measuring up to } \\
\text { um, running right } \\
\text { columellae that } \\
\text { at best only part } \\
\text { the grain, bran } \\
\text { double layer; } \\
\text { the mural mesh; } \\
\text { this way; muri } \\
\text { aperture margins } \\
\text { exine thickness } \\
\text { margins infolde } \\
\text { spherules and cl. }\end{array}$ & $\begin{array}{l}\text { M (All observations made with SEM). } \\
\text { lpate pollen, length } 14.51 \text { ( } 17.1) 19.36 \text { um, width } 6.45 \\
\text { Width varies with the condition of the apertures; } \\
\text { have closed apertures with infolded margins, the more } \\
\text { have gaping apertures. Exine semitectate, striate. } \\
\text { cross section, width } 0.15(0.27) 0.38 \text { um, height } 0.15 \\
\text { sculpted with conspicious transverse ribbing, ribs } \\
0.05 \text { um wide, placed at regular intervals up to } 0.05 \\
\text { t round the murus; muri supported on very inconspicious } \\
\text { are difficult to observe through the mat of muri, being } \\
\text { tially visible; muri meander freely over the surface of } \\
\text { ching, anastomosing and overlapping, at times forming a } \\
\text { some muri end blindly, their ends projecting up through } \\
\text { others loop sharply, these loops also projecting in } \\
\text { dip into the aperture, then run parallel along the } \\
\text { Nexine smooth, much thinner than the sexine. Total } \\
\text { up to } 0.54 \text { um. Apertures long, initially with their } \\
\text { d, later gaping open. Margins sculpted with exinous } \\
\text { avae. }\end{array}$ \\
\hline Variation records & $\mathrm{N}$ Recorded under $\mathrm{M}$ \\
\hline Number of specimens & L $\quad 12$ \\
\hline Locality & $\begin{array}{l}\text { C Mersa Matruh borehole, N.W. Desert, Egypt. } \\
\text { Grid ref. } 31^{\circ} 19 \cdot 43.00 " \mathrm{~N} 27^{\prime} 16,07.00 " \mathrm{E}\end{array}$ \\
\hline Rock formation & D Kharita Member \\
\hline Sample position & E MMX-1 7890, at depth 7890 feet. \\
\hline Sample li thology & F Medium pale yellow sandstone \\
\hline Preservation & $P \quad$ Good \\
\hline Repository & $\begin{array}{l}\text { R Dept. Earth Sciences, Cambridge University, U.K. } \\
\text { Preps. JP 066, 180, Stubs JPS 228, 229, 230, } 249 .\end{array}$ \\
\hline Earlier Records & S None \\
\hline Conclusion & T Ends. \\
\hline
\end{tabular}

Table 1

\section{Genusbox STRIOTRI}

Descriptive limits: Semitectate, striate, tricolpate pollen.

\section{STRIOTRI-SEGMUR}

Pl. 1, figs. 1-10, Table 1.
Occurence of STRIOTRI-SEGMUR

The youngest record of STRIOTRI-SEGMUR is from core sample MMX-1 7695 (Aptian). CfA records range down to the earliest reliable record of STRIOTRI-SEGMUR, which is in the Early Aptian 

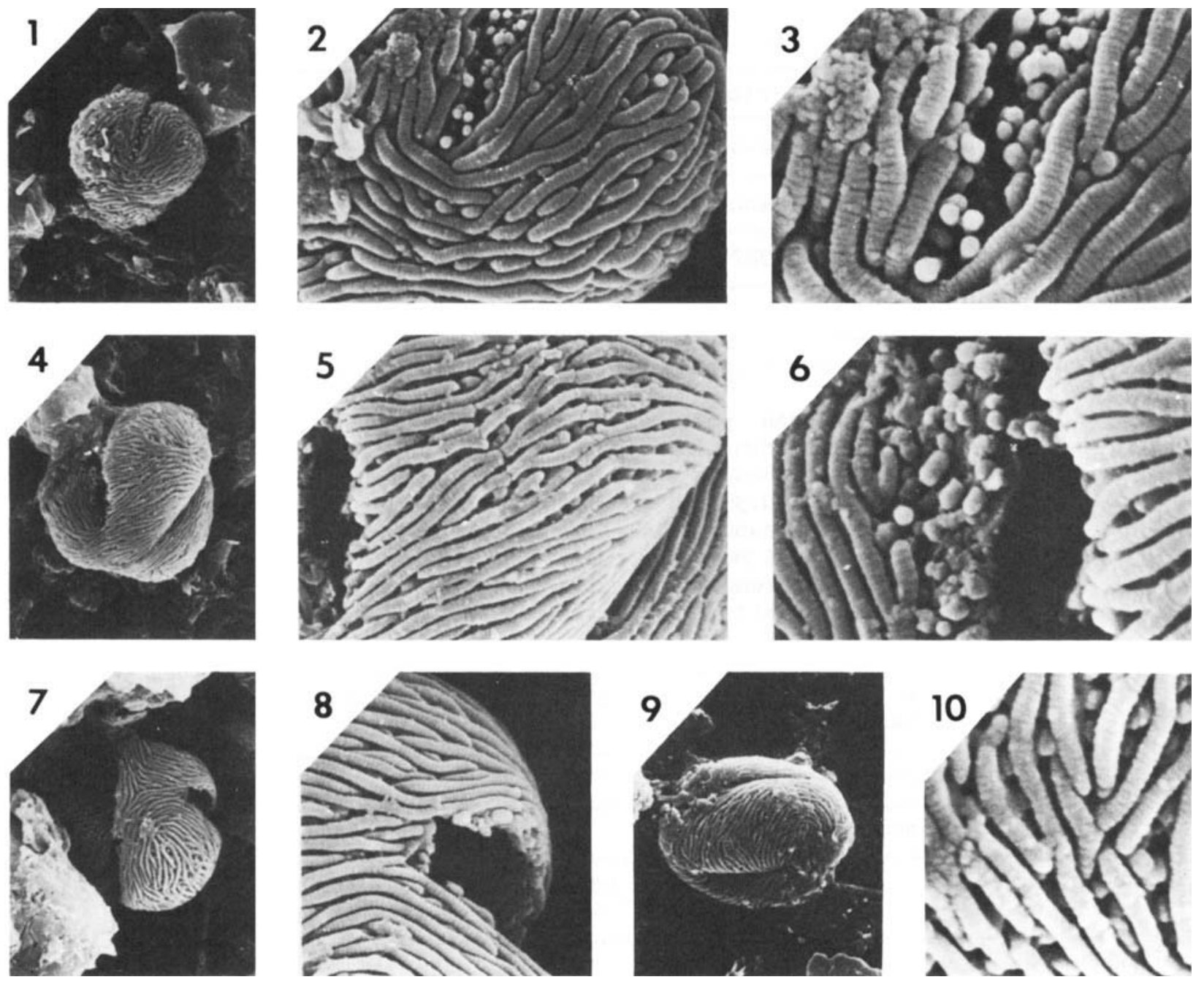

PLATE 1: STRIOTRI-SEGMUR

Figs. 1, 2, 3. Grain number JPR 152/1 (BIORECORD), sample MMX-1 7890, prep. JP 066, stub JPS 228, coordinates $824 \times 227$ 1. $\times 1600$, neg. $189 / 36,2 . \times 7000$, neg. $189 / 37,3 . \times 13000$, neg. $189 / 38$.

Figs. 4, 5, 6. Grain number JPR i52/2 (BIORECORD), sample MMX-1 7890, prep. JP 066, stub JPS 228, coordinates $818 \times 345$.

4. $\times 1600$, neg. $189 / 22,5 . \times 7000$, neg. $189 / 23,6, \times 13000$, neg. $189 / 24$.

Figs. 7, 8. Grain number JPR 152/3 (BIORECORD), sample MMX-1 7890, prep. JP 066, stub JPS 228, coordinates $767 \times 328$.

7. $\times 1600$, neg. $193 / 7,8 . \times 7000$, neg. $193 / 8$.

Figs. 9, 10. Grain number JPR 152/4 (BIORECORD), sample MMX-1 7890, prep. JP 066, stub JPS 228, coordinates $725 \times 274$.

9. $\times 1600$, neg. $194 / 3,10 . \times 7000$, neg. $194 / 5$.

core sample $\mathrm{MMX}-1$ 9522, although a $\mathrm{CfA}$ record occurs in one cuttings sample below this (MMX-1 $10240^{*}$, Early Aptian). Its greatest abundance is in sample MMX-17890 where it accounts for $15 \%$ of the total angiosperms present. The following comparison records of STRIOTRI-SEGMUR have been deposited in Cambridge (sample number MMX-1 . . .number of specimens); CfA: 7695/7, 7875/3, 7880/1, 7885/1, 8577/ $2,8818 / 8,9522 / 2,10240 * / 1$. 


\begin{tabular}{|c|c|}
\hline \multicolumn{2}{|r|}{ REFERENCE TAXON DESCRIPTION } \\
\hline Group of organisms & J Tricolpate pollen \\
\hline Sequence age & G Mesozolc / Cretaceous / Early Aptian \\
\hline Originator & A Penny,J.H.J. Cambridge University, U.K. \\
\hline Origination date & B 1987, July 20, twelve 00 . \\
\hline Taxon name & K BIorecord STRIOTRI-OVAL \\
\hline $\begin{array}{l}\text { Description } \\
\text { Prolate trice } \\
\text { (15.7) } 19.0 \text { um } \\
\text { striate. Muri } \\
\text { height } 0.15 \text { (0) } \\
\text { supported on inc } \\
\text { hard to observe; } \\
\text { branching and } \\
\text { aperture margins } \\
\text { mat of muri. } \\
\text { slightly infoldec } \\
\text { other two, giving } \\
\text { from some angles. }\end{array}$ & $\begin{array}{l}\text { M (All observations made with SEM). } \\
\text { olpate pollen with gently rounded ends. Length } 13.0 \\
\text { width } 8.07 \text { ( } 11.45) 14.19 \text { um. Exine semitectate, } \\
\text { rounded in cross section, width } 0.15(0.28) 0.39 \text { um, } \\
\text {.28) } 0.35 \text { um, sculpted with faint transverse ridges, } \\
\text { onspicuous columellae up to } 0.1 \text { um tall which are very } \\
\text { muri meander freely over grain surface, overlapping, } \\
\text { anastomosing regularly but running parallel along } \\
\text { Nexine smooth, visible only occasionally through the } \\
\text { Apertures parailel to the long axis, with margins } \\
\text { d and poorly-defined; one aperture is longer than the } \\
\text { g the grain a slightiy asymmetrical outline when viewed } \\
\text { - }\end{array}$ \\
\hline Variation records & $\mathrm{N}$ Recorded under $\mathrm{M}$ \\
\hline Number of specimens & L 6 \\
\hline Locality & $\begin{array}{l}\text { C Mersa Matruh borehole, N.W. Desert, Egypt. } \\
\text { Grid ref. } 31^{\circ} 19,43.00 " \mathrm{~N} 27^{\circ} 16,07.00 " \mathrm{E}\end{array}$ \\
\hline Rock formation & D Matruh Shale \\
\hline Sample position & E MMX-1 10350, at depth 10350 feet. \\
\hline Sample li thology & F Dark shale \\
\hline Preservation & P Good \\
\hline Repository & $\begin{array}{l}\text { R Dept. Earth Sciences, Cambridge University, U.K. } \\
\text { Preparation JP 094, Stubs JPS } 139,140 .\end{array}$ \\
\hline Earlier Records & $S$ None \\
\hline Conclusion & T Ends. \\
\hline
\end{tabular}

Table 2

STRIOTRI-OVAL

Pl. 2, figs. 1-10, Table 2 .

Occurrence of STRIOTRI-OVAL

The youngest record of STRIOTRI-OVAL is in core sample MMX-1 7875 (Late Aptian). CfA records range down to the earliest reliable record in core sample MMX-1 9508 (Early Aptian). CfA records also occur below this in cutting samples MMX-1 10350* (Early Aptian) and MMX-1 11620* (? Late Barremian).

It is most abundant is in the two deepest cuttings samples mentioned above, where it accounts respectively for 10.9 and $12.5 \%$ of the total angiosperms present. In the cores its highest abundance is in sample MMX-1 9560 (6.9\%). 

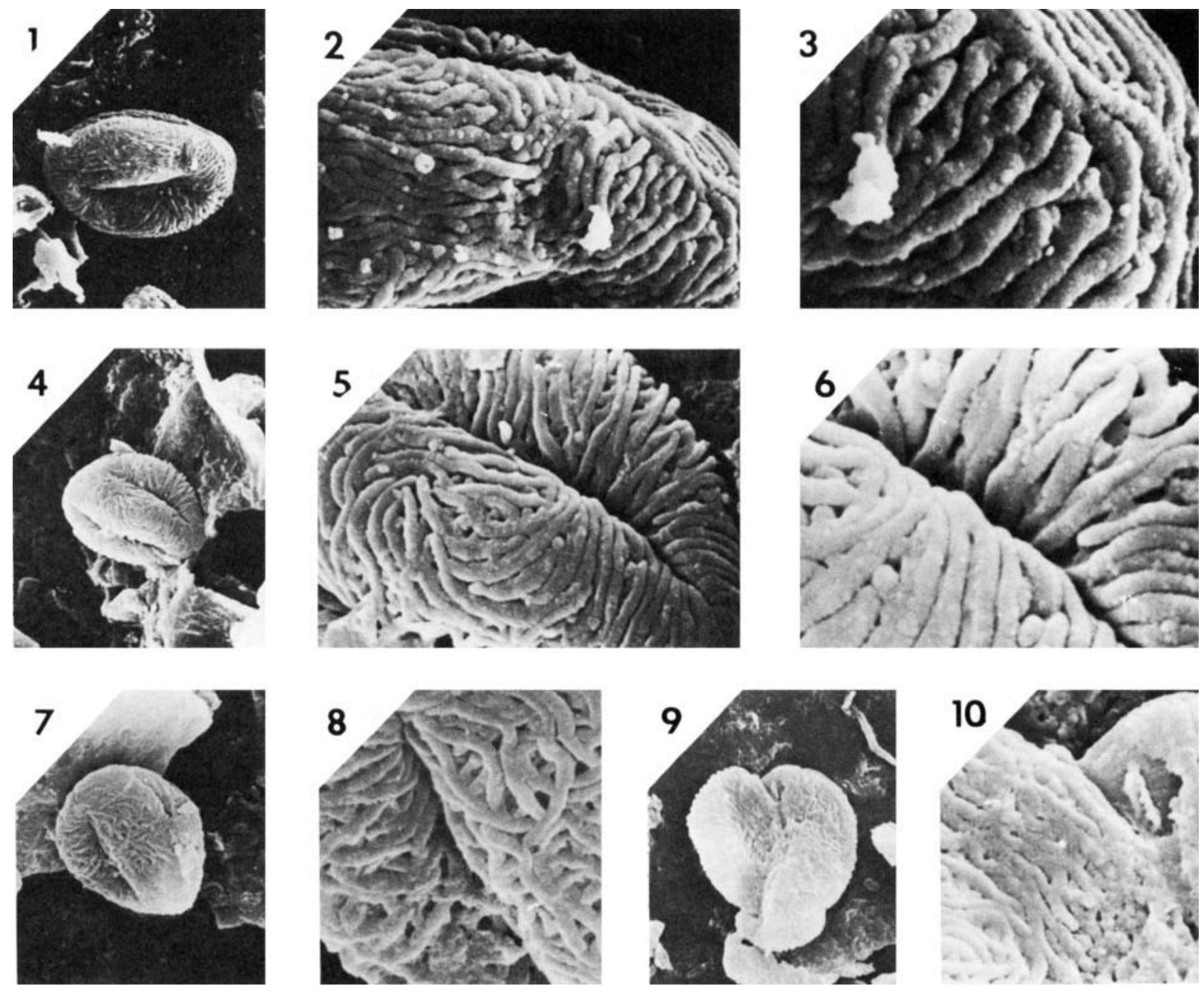

\section{PLATE 2: STRIOTRI-OVAL}

Figs. 1, 2, 3. Grain number JPR 169/1 (CfA), Sample MMX-1 8597, prep. JP 023, stub JPS 92, coordinates $825 \times 255$.

1. $\times 1600$, neg. $257 / 28,2 . \times 7000$, neg. $257 / 29,3 . \times 13000$, neg. $257 / 30$.

Figs. 4, 5, 6. Grain number JPR 215/1 (CfA), sample MMX-1 7890, prep. JP 066, stub JPS 228, coordinates $872 \times 274$.

4. $\times 1600$, neg. 191/01, 5. $\times 7000$, neg. 191/02, 6. $\times 13000$, neg. 191/03.

Figs. 7, 8. Grain number JPR 151/1 (BIORECORD), sample MMX-1 10350*, prep. JP 094, stub JPS 139, coordinates $808 \times 342$.

7. $\times 1600$, neg. $120 / 10,8 . \times 7000$, neg. $120 / 11$.

Figs. 9, 10. Grain number JPR 567/3 (CfA), sample MMX-1 8900*, prep. JP 091, stub JPS 133, coordinates $795 \times 217$.

9. $\times 1600$, neg. $106 / 28,10 . \times 7000$, neg. 106/29.

Although the possibility of caving in the two deepest cutting samples cannot be ignored, it is interesting to note the high abundance of STRIOTRI-OVAL there relative to the other angiosperms present (which could themselves have been subject to caving), especially as the next highest aundance is in the deepest core sample. This suggests that this pollen type may have reached its acme in the early part of its reported range (i.e. in the Early Aptian). The following comparison records have been deposited in Cambridge (sample number $\mathrm{MMX}-1 .$. number of specimens); CfA: $7875 / 3,7890 / 2,8577 / 6,8597 / 1,8810 / 4,8818 / 2,8900^{*} / 3$, $9182 / 3,9508 / 2,11620 * / 1$. 


\begin{tabular}{|c|c|}
\hline \multicolumn{2}{|r|}{ REFERENCE TAXON DESCRIPTION } \\
\hline Group of organisms & J Tricolpate pollen \\
\hline Sequence age & G Mesozolc / Cretaceous / Early Aptian \\
\hline Originator & A Penny,J.H.J. Cambridge University, U.K. \\
\hline Origination date & B 1987, July 20 , Twelve 20 \\
\hline Taxon name & K BIorecord STRIOTRI-SMOOTHMUR \\
\hline $\begin{array}{l}\text { Description } \\
(10.54) \quad 17.1 \text { um } \\
\text { open the apert } \\
\text { striate. Muri } \\
\text { height } 0.15(0.2 \\
\text { are at best } \\
\text { meander freely } \\
\text { overlapping fre } \\
\text { between the mu } \\
\text { attained. Muri } \\
\text { smooth. Apertur } \\
\text { sparsely sculpte }\end{array}$ & $\begin{array}{l}\text { M (All observations made with SEM). } \\
\text { lpate pollen, length } 12.58 \text { (15.46) } 19.03 \text { um, width } 6.45 \\
\text { Width varies depending on the apertures; the more } \\
\text { ure the greater the grain width. Exine semitectate, } \\
\text { rounded in cross section, width } 0.15(0.25) \text { 0.31um, } \\
0.23 \text { um, smooth, supported on small columellae which } \\
\text { nly partially visible through the mat of muri; muri } \\
\text { over grain surface, branching, anastomosing and } \\
\text { quently. There are occasional transverse connections } \\
\text { ri, but a true strioreticulate condition is never } \\
\text { run parallel along the aperture margins. Nexine } \\
\text { es long, with inrolled margins or gaping open, margins } \\
\text { d with irregular exinous spherules. }\end{array}$ \\
\hline Variation records & $\mathrm{N}$ Recorded under $\mathrm{M}$ \\
\hline Number of specimens & L 20 \\
\hline Locality & $\begin{array}{l}\text { C Mersa Matruh borehole, N.W. Desert, Egypt. } \\
\text { Grid ref. } 31^{\circ} 19{ }^{\prime} 43.00 " \text { N } 27^{\prime} 16,07.00 " \text { E }\end{array}$ \\
\hline Rock formation & D Matrun Shale \\
\hline Sample position & E MMX-1 10479, at depth 10479 feet. \\
\hline Sample lithology & E Dark shale \\
\hline Preservation & $P$ Good \\
\hline Repository & $\begin{array}{l}\text { R Dept. Earth Sciences, Cambridge University, U.K. } \\
\text { Prep. JP 034, Stubs JPS } 83,84,183,184,213,214 .\end{array}$ \\
\hline Earlier Records & S None \\
\hline Conclusion & $\mathrm{T}$ Ends. \\
\hline
\end{tabular}

Table 3

STRIOTRI-SMOOTHMUR

Pl. 3, figs. 1-10, Table 3 .

Occurrence of STRIOTRI-SMOOTHMUR

Apart from one isolated CfA record in cuttings sample MMX-1 7310* (Late Aptian), the youngest record of STRIOTRI-SMOOTHMUR is in core sample MMX-1 8597 (Mid Aptian). CfA records range down to the deepest record in sample MMX-1 10479 (Early Aptian). STRIOTRI-SMOOTHMUR increases in abundance downhole, accounting for $38.5 \%$ of the 

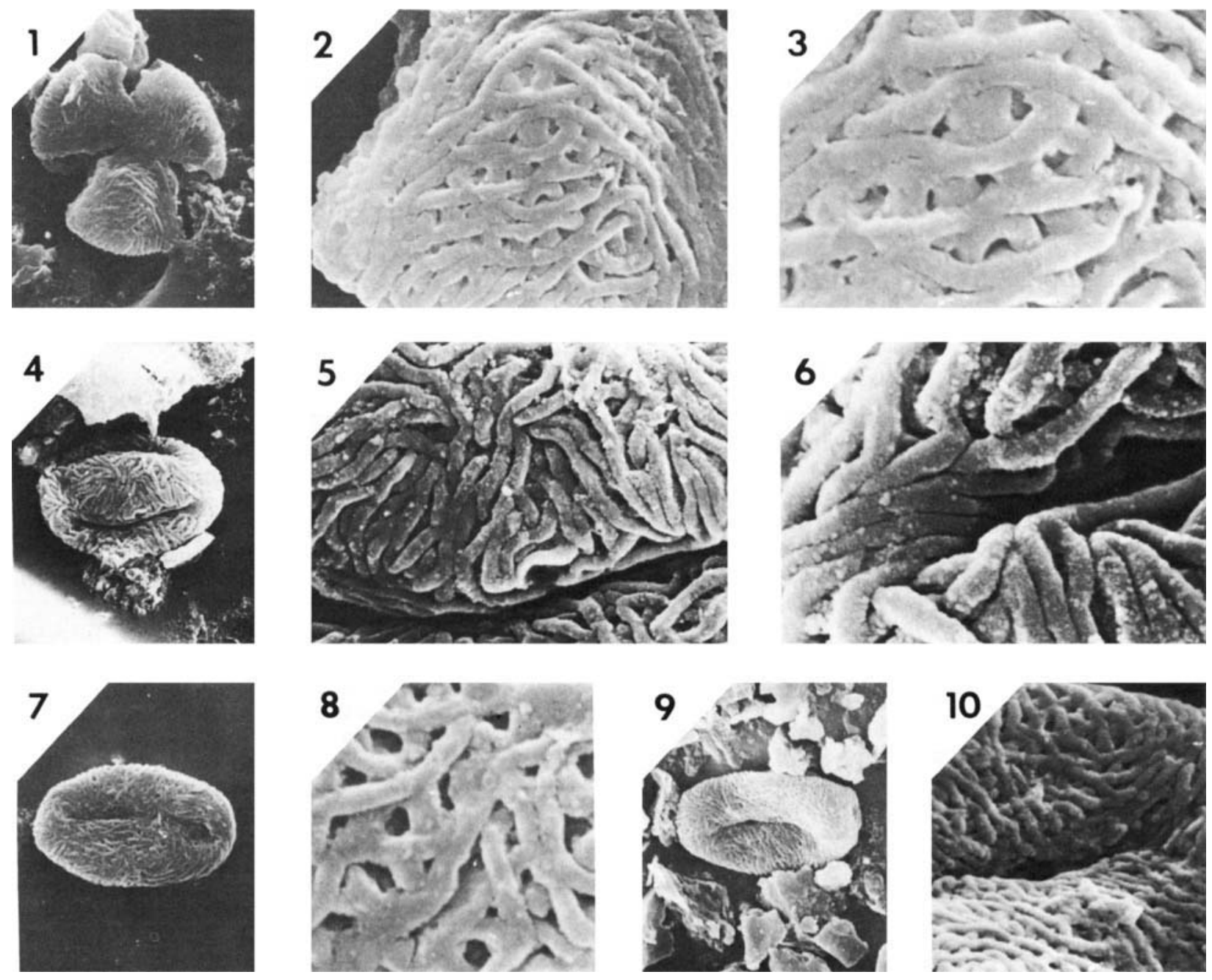

PLATE 3: STRIOTRI-SMOOTHMUR

Figs. 1, 2, 3. Grain number JPR 577/13 (BIORECORD), sample MMX-1 10479, prep. JP 034, stub JPS 213, coordinates $870 \times 351$.

1. $\times 1600$, neg. $174 / 36,2 . \times 7000$, neg. $174 / 37,3 . \times 13000$, neg. $174 / 40$.

Figs. 4, 5, 6. Grain number JPR 576/1 (CfA), sample MMX-1 10240*, prep. JP 103, stub JPS 209, coordinates $842 \times 388$.

4. $\times 1600$, neg. $179 / 17,5 . \times 7000$, neg. $179 / 18,6 . \times 13000$, neg. $257 / 27$.

Figs. 7, 8. Grain number JPR 577/16 (BIORECORD), sample MMX-1 10479, prep. JP 034, stub JPS 213, coordinates $782 \times 288$.

7. $\times 1600$, neg. $176 / 26,8 . \times 7000$, neg. $176 / 27$.

Figs. 9, 10. Grain number JPR 575/1 (CfA), sample MMX-1 9508, prep. JP 024, stub JPS 107, coordinates $772 \times 328$.

9. $\times 1600$, neg. $88 / 21,10 . \times 7000$, neg. $88 / 22$.

angiosperm representation in the deepest core sample of its range. The following comparison records of STRIOTRI-SMOOTHMUR have been deposited in Cambridge (sample number MMX-1. . /number of specimens); CfA: $7310 * / 1,8597 / 1,9182 / 1,9508 / 1$, 10240*/5; CfB : 8818/2. 


\begin{tabular}{|c|c|}
\hline \multicolumn{2}{|r|}{ REFERENCE TAXON DESCRIPTION } \\
\hline Group of organisms & $J$ Tricolpate pollen \\
\hline Sequence age & G Mesozoic / Cretaceous / Aptian \\
\hline Originator & A Penny,J.H.J. Cambridge University, U.K. \\
\hline Origination date & B 1987, July 20, fourteen 30 \\
\hline Taxon name & K Blorecord STRIORET-SMOOTH \\
\hline $\begin{array}{l}\text { Description } \\
\text { Prolate trico } \\
\text { um. Exine semi } \\
\text { height } 0.23 \text { (0 } \\
\text { anastamosing an } \\
\text { margins. Exine } \\
\text { the grain the m } \\
\text { which measure } 0 \\
\text { be the result of } \\
\text { be bounded by on } \\
\text { small columellae } \\
0.23 \text { um tall and } \\
\text { thick. Total } \\
\text { entire length } 0 \\
\text { small spherules. }\end{array}$ & $\begin{array}{l}\text { M (All observations made with SEM). } \\
\text { lpate pollen, length } 21.6 \mathrm{um} \text {, width } 16.12 \text { (17.63) } 19.36 \\
\text { tecate, striate. Muri smooth, rounded in cross section, } \\
\text {.3) } 0.46 \mathrm{um} \text {, width } 0.15(0.29) 0.35 \mathrm{um} \text { branching, } \\
\text { d interwoven; muri running parallel along the colpus } \\
\text { striate on the grain ends, but in the central areas of } \\
\text { puri become more widely-spaced and tend to form lumina } \\
.15(0.59) 1.23 \text { um in diameter. The lumina may either } \\
\text { a gap formed by the random crossing of the muri or may } \\
\text { eontinuous section of murus. Muri supported on very } \\
\text { that are difficult to observe; columellae } 0.12 \text { (0.14) } \\
0.12 \text { (0.15) } 0.23 \text { um wide. Nexine smooth, up to } 0.3 \text { um } \\
\text { exine thickness up to } 1.0 \text { um. Apertures long, running } \\
\text { the grain and onto the ends, margins sculpted with } \\
\text { f the }\end{array}$ \\
\hline Variation records & $\mathrm{N}$ Recorded under $\mathrm{M}$ \\
\hline Number of specimens & L 5 \\
\hline Locality & $\begin{array}{l}\text { C Mersa Matruh borehole, N.W. Desert, Egypt. } \\
\text { Grid ref. } 31^{\circ} 19 \cdot 43.00 " \mathrm{~N} 27^{\prime} 16,07.00 " \mathrm{E}\end{array}$ \\
\hline Rock formation & D Kharita Member \\
\hline Sample position & E MMX-1 7890 , at depth 7890 feet. \\
\hline Sample li thology & F Medium pale yellow sandstone \\
\hline Preservation & P Good \\
\hline Repository & $\begin{array}{l}\text { Rept. Earth Sclences, Cambridge University, U.K. } \\
\text { Preps. JP } 066,180 \text {, Stubs JPS } 228,229,230,249 \text {. }\end{array}$ \\
\hline Earlier Records & S None \\
\hline Conclusion & T Ends. \\
\hline
\end{tabular}

Table 4

Genusbox STRIORET

Descriptive limits: Semitectate, striotreticulate tricolpate pollen.

\section{STRIORET-SMOOTH}

Pl. 4, figs. 1-10, Table 4.
Occurrence of STRIORET-SMOOTH

The youngest record of STRIORET-SMOOTH is in core sample MMX-1 7875 (Late Aptian). CfA records occur below this, the deepest being in core sample 

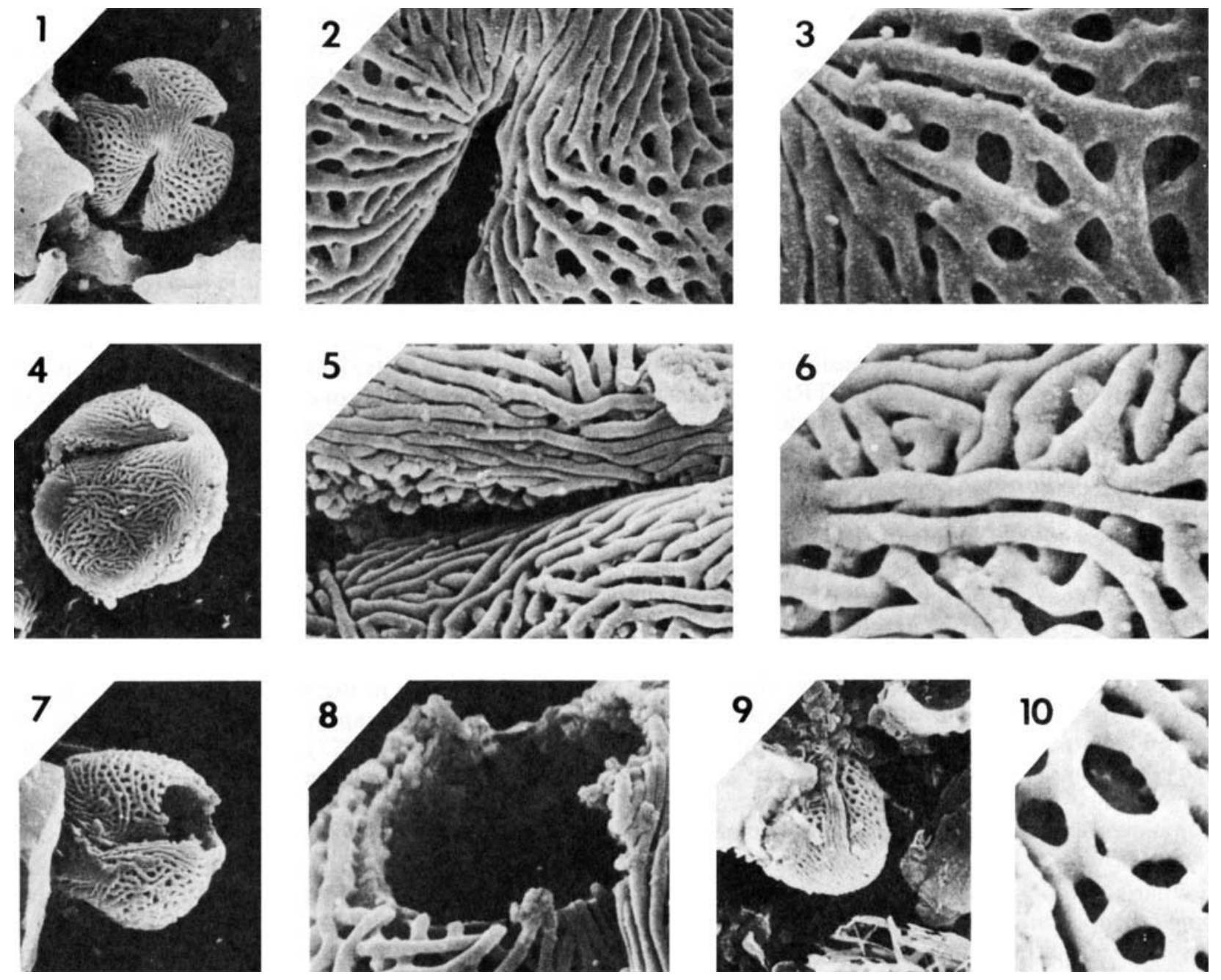

\section{PLATE 4: STRIORET-SMOOTH}

Figs. 1, 2, 3. Grain number JPR 252/1 (CfA), sample MMX-1 7885, prep. JP 008, stub JPS 58, coordinates $843 \times 283$.

1. $\times 1600$, neg. $257 / 135,2 . \times 7000$, neg. $257 / 134,3 . \times 13000$, neg. $257 / 133$.

Figs. 4, 5, 6. Grain number JPR 155/4 (BIORECORD), sample MMX-1 7890, prep. JP 066, stub JPS 228, coordinates $888 \times 347$.

4. $\times 1600$, neg. $191 / 28,5 . \times 7000$, neg. $191 / 29,6 . \times 13000$, neg. $191 / 30$.

Figs. 7, 8. Grain number JPR 155/2 (BIORECORD), sample MMX-1 7890, prep. JP 066, stub JPS 228, coordinates $815 \times 233$.

7. $\times 1600$, neg. $189 / 32,8 . \times 7000$, neg. $189 / 33$.

Figs. 9, 10. Grain number JPR 155/1 (BIORECORD), sample MMX-1 7890, prep. JP 066, stub JPS 228, coordinates $885 \times 256$.

9. $\times 1600$, neg. $191 / 23,10 . \times 13000$, neg. $191 / 25$.

MMX-1 9182 which is of Early Aptian age. It is rare, representing a maximum of $6.3 \%$ of the total angiosperm complement in sample MMX-1 7890, elsewhere represented only by isolated grains. The following comparison records of STRIORET-SMOOTH have been deposited in Cambridge (sample number MMX-1 . .number of specimens); CfA: 7875/1, 7885/1, 9182/1. 


\section{DISCUSSION AND COMPARISON}

\section{a. Recognition of taxa}

The four striate taxa recorded above are distinguished from one another on the structure of the tectum and on aperture configuration.

Two of them, STRIORET-SMOOTH and STRIOTRI-SMOOTHMUR, have unsculpted muri. STRIORET-SMOOTH is easily distinguished because it has a strioreticulate exine in the central part of the grain, while STRIOTRI-SMOOTHMUR has a purely striate sexine.

For the other two, STRIOTRI-OVAL and STRIOTRI-SEGMUR, the only easily recognisable difference is in the apertures. STRIOTRI-OVAL has two short colpi, the third being slightly longer, while STRIOTRI-SEGMUR has longer colpi which are of equal length. In addition, STRIOTRI-SEGMUR has a well-developed sculture of irregular exinous spherules on the aperture membrane, a feature which is absent in STRIOTRI-OVAL. This feature is unfortunately of limited use as it can only be seen on the more expanded specimens. The sexine is also slightly different. In both the muri meander freely over the grain surface, branching, anastamosing and overlapping. However in STRIOTRI-SEGMUR there are frequent blind projections and sharp loops of the muri which project up through the mural network. This form also has a tendency to have a double layer of muri in the sexine and sometimes appears to have a pseudoreticulate base layer as a result.

\section{b. Comparison with existing taxa}

Comparison of the Egyptian pollen with published species has been difficult because most published data are based on light microscope observations. This makes it impossible to make clear comparisons, particularly as the Egyptian forms are, with the possible exception of STRIORET-SMOOTH, themselves indistinguishable without the use of SEM. Nevertheless, comparable forms do exist which are discussed below.

Grains with a strioreticulate sexine similar to that of STRIORET-SMOOTH include Striatopollis paraneus (Norris) Singh, 1971, Retitricopites vermimurus Brenner, 1963 and Striatricopites reticulatus Regali et al., 1974.

S. paraneus is known from sediments of Albian to Cenomanian age in Canada (Norris, 1967; Singh, 1971; Playford, 1971), U.S.A. (Doyle \& Robbins, 1977; Hedlund \& Norris, 1968; Srivastava, 1975) and from Australia (Dettmann, 1973). Dettmann's (1973) SEM details reveal secondary transverse striations on the muri (PI. 2, figs. 21 and 22) which she points out as being invisible at magnificatons of less than $\times 3000$. This clearly refutes any relation between $S$. paraneus and STRIORET-SMOOTH. S. paraneus is, however, quite similar to STRIOTRI-SEGMUR in its possession of transversely-striate muri and the irregular projec- tions which were interpreted by Dettman (1973) as free standing columellae on the aperture membrane. In addition, there is good agreement between the sizes of the two forms. Also of interest is the secondary layer in the sexine of STRIOTRI-SEGMUR which sometimes forms a pseudoreticulum. This might agree with the observation of the pseudoreticulate sexine of $S$. paraneus, particularly apparent in the light microscope figures of Doyle \& Robbins (1977). However, STRIOTRI-SEGMUR and $S$. paraneus differ in minor details, especially in the dimensions of the muri which are larger in $S$. paraneus, with a much more solid appearance. STRIOTRI-SEGMUR occurs in Aptian strata leading to the conclusion that it might represent a precursor of $S$. paraneus.

Striatricolpites reticulatus Regali et al., 1974, which is of possible Aptian age, has a stratigraphic range similar to that observed for STRIOTRI-SMOOTHMUR. However, it is entirely different, being much larger $(52 \mu \mathrm{m})$ and therefore cannot be compared.

Retitricolpites vermimurus was described from the Potomac by Brenner (1963) and was also illustrated by Doyle \& Robbins (1977). It is similar to STRIORETSMOOTH, both in the size and in the possession of a pseudoreticulum (especially clear in Pl. 4, fig. 30 of Doyle \& Robbins, 1977). However, the two cannot be compared further without SEM details for the North American examples.

Laing (1975) illustrated the species Striatopollis sarstedtensis Krutzsch, 1959 from Albian to Cenomanian strata of S. England and N. France, providing useful SEM illustrations. Although he mentions a polar microreticulum, this feature is not obvious from the SEM picture, suggesting that this is again the result of the existence of a secondary layer in the sexine. The muri show a clear orientation parallel to the colpi, a feature which is also seen in the specimen illustrated from Portugal (Groot \& Groot, 1962) and the Eastern North Atlantic (Kotova, 1978). Laing also points out the presence of "small cones" on the muri which are equivalent to the transverse striae on the muri of STRIOTRI-OVAL and STRIOTRI-SEGMUR. $S$. sarstedtensis is not, however, sufficiently similar to either of these types to invoke any specific connection.

Other species with comparable exine structure include Striatopollis dubius Jardine \& Magloire, 1965 and Striopollenties terasmei Rouse, 1962. Unfortunately SEM detail is not yet available for either. However, both bear a resemblance to STRIOTRI-OVAL, although $S$. terasmei is less likely to compare as it occurs only in the Late Cretaceous and is also larger.

S. dubius is Albian to Cenomanian in stratigraphic distribution and is known from offshore N. America (Hochuli \& Kelts, 1980), S. America (Regali et al., 1974) and from offshore and mainland W. Africa (Jardine \& Magloire, 1965; Morgan, 1976; Kotova, 
1978). It is very similar to STRIOTRI-OVAL in the way the muri run down into the colpi and then turn to follow the colpus margins (see Pl. 12, figs. $12 \mathrm{a}, \mathrm{b}, \mathrm{c}$ of Kotova, 1978). However, it differs from STRIOTRI-OVAL in being larger.

$S$. dubius is also quite similar to STRIOTRISMOOTHMUR but is again larger. In addition, STRIOTRI-SMOOTHMUR has a more random arrangement of its muri, which do not show such a clear tendency to run perpendicularly into the colpi as is the case in STROTRI-OVAL.

There have been several unidentified striate tricolpates in the literature. Of particular interest are the possibly Aptian examples of Doyle et al. (1977) and Gubeli et al. (1985, no illustration), because they coincide better with the ranges observed for the Egyptian species. Unfortunately these forms are not yet sufficiently well documented to allow comparison.

\section{DISCUSSION}

Statigraphic Setting. The almost exlusively terrestrial character of the palynoflora has presented problems with the dating of the sequence in Mersa Matruh 1, mainly due to the paucity of dinocysts for independent control. Thus the chronology of the sequence is based entirely on observations of the spores and pollen which are present.

The earliest angiosperms in Mersa Matruh 1 occur in sediments which are of probable Late Barremian age (Penny, 1986a) and compare well with those of other Late Barrenian floras from W. Africa (Doyle et al., 1977), N. America (Doyle et al., 1975; Hickey \& Doyle, 1977) and S. England (Hughes et al., 1979), particularly with respect to the Stellatopollis forms which are present.

The strata immediately underlying the first tricolpates have been dated as Late Barremian to Earliest Aptian and are marked by the first occurrences of Afropollis Doyle et al., 1982. Of these, the earliest known specimens are possibly Late Barremian in age (Penny, 1986b). Also occurring for the first time at this level is the Retimonocolpites-reticulatus-peroreticulatus group of Schrank (1982), which has a ?late Barremian earliest appearance (Penny, 1988). It is just above these strata that the first striate tricolpates occur, close to the lower limit of definitely Aptian strata. These are also the earliest tricolpates to occur in the well. In other areas the first tricolpates to appear are reticulates (e.g. Herngreen, 1975; Doyle et al., 1977; Gebeli et al., 1985). The apparent reversal of the situation in Egypt is almost certainly a false impression due to the extreme rarity of reticulates in older strata. This possibility is reinforced by the appearance of a single reticulate tricolpate grain in the Barremian core sample $\mathbf{M M X - 1}$ 11832. The upper range of the striates coincides with the ranges of Retimonocolpites mawhoubensis Schrank,
1983 and Reyrea polymorphus Herngreen, 1973. $R$. mawhoubensis was described from the Late Aptian to possibly Early Albian strata penetrated by the Mawhoub West 2 well (Schrank, 1983) which is to the south of Mersa Matruh 1. R. polymorphus has a similar range (Herngreen, 1973; Thusu \& Van der Eem, 1985; Regali et al., 1974). The age inferred by the presence of these two species in Mersa Matruh 1 is therefore Late Aptian to Early Albian. The striates disappear just after the last occurrence of $R$. mawhoubensis in strata of presumed early Albian age.

Early Tricoplate Succession. The possible appearance of striates before reticulates is probably due to the rarity of reticulates in earlier strata rather than to a reversal of the recognised evolutionary succession. Nevertheless, it is interesting that in the early part of their range the striates account for the great majority of the tricolpate grains which were recovered. This may reflect a local predominance of striate producers in the flora. In terms of the actual numbers of taxa which are present there is greater parity, although the early reticulates are all sporadic in occurrence. This situation is reversed in the Late Aptian-Early Albian succession as the striates decline and reticulates become more common, both in the number of taxa and in the number of specimens recovered.

Doyle et al. (1977) indicate the possibility that the appearance of tricolpates in the W. African sequence could be used as a stratigraphic reference to identify the lower limit of the Aptian. However, it is possible that the tricolpates appear earlier in Eastern Gondwana. This is indicated by the observations of Brenner (1974, 1976) who found tricolpates in possible Barremian strata from boreholes in the Northern Negev of Israel. Support for this contention is provided by the single occurrence of a reticulate tricolpate in the probable Barremian strata of Mersa Matruh 1.

Unfortunately both the observations of Brenner $(1974,1976)$ and those in the present study are subject to a certain degree of uncertainty. In the Negev case caving in the well may have led to downhole contamination and in Mersa Matruh (although the grain in question did come from a core sample) the number of specimens is too small.

For the present the earliest record of tricolpates in Eastern Gondwana must be viewed as possible earliest Aptian sensu Doyle et al. (1977). This is in spite of the tantalising suggestion that this early stage of angiosperm pollen evolution might yet be pushed into the Barremian succession.

\section{ACKNOWLEDGEMENTS}

This reserach was carried out whilst I was in receipt of a NERC CASE studentship with Robertson Research International Limited (Penny, 1986b), who also kindly supplied the samples and obtained permission 
from the drilling company for me to publish my results.

I thank Dr. N. F. Hughes, who supervised my research, for much encouragement and helpful discussion and Dr. J. F. Laing of Robertson Research for useful discussion.

Mr. D. Newling and Mr. R. Lee were of invaluable assistance with the photography. I am very grateful to the Department of Earth Sciences, Cambridge University, for the use of their facilities during the preparation of this paper.

\section{Manuscript received August 1987}

Revised manuscript received February 1988

\section{REFERENCES}

Brenner, G. J. 1963. The spores and pollen grains of the Potomac Group of Maryland. Bull. Md. Dep. Geol. Mines, 27, 215 pp.

Brenner, G. J. 1974. Palynostratigraphy of the Lower Cretaceous Gevar'am and Talme Yafe formations in the Gevar'am 2 well. Geol. survey of Israel Bull., 59, 1-27.

Brenner, G. J. 1976. Middle Cretaceous floral provinces and early migrations of angiosperms. In Beck, C. B. (Ed.), Origin and early evolution of angiosperms, pp. 23-47. Columbia University Press.

Dettman, M. E. 1973. Angiospermous pollen from Albian to Turonian sediments of Eastern Australia. Spec. Publ. No. 4, Geol. Soc. Austr., 3-34.

Doyle, J. A., Biens, P., Doerenkamp, A. \& Jardine, S. 1977. Angiosperm pollen from the pre Albian Lower Cretaceous of equatorial Africa. Bull. Centre Rech. Explor.-Prod. Elf-Aquitaine, 1 (2), 451-473.

Doyle, J. A., Jardine, S. \& Doerenkamp, A. 1982. Afropollis, a new genus of early angiosperm pollen, with notes on the Cretaceous palynostratigraphy and palaeoenvironments of Northern Gondwana. Bull. Centres Rech. Explor.-Prod. Elf-Aquitaine, 6 (1), 39-117.

Doyle, J. A. \& Robbins, E. I. 1977. Angiosperm pollen zonation of the continental Cretaceous of the Atlantic coastal plain and its application to deep wells in the Salisbury Embayment. Palynology, 1, Proc. VIIIth Ann. Mtg. AASP, Houston, 43-78.

Doyle, J. A., Van Campo, M. \& Lugardon, B. 1975. Observations on exine structure of Eucommiidites and Lower Cretaceous angiosperm pollen. Pollen et Spores, 17 (3), 429-486.

Groot, J. J. \& Groot, C. R. 1962. Plant microfossils from Aptian, Albian and Cenomanian deposits of Portugal. Com. Serv. Geol. Portugal, 46, 133-171.

Gubeli, A. A., Hochuli, P. A. \& Wildi, W. 1985. Lower Cretaceous turbiditic sediments from the Rif chain (Northern Morocco) - palynology, stratigraphy and palaeogeographic setting. Geol. Rundsch., 73 (3), 1081-1114.

Hammen, T. van der 1956. Description of some genera and species of fossil pollen and spores. Bol. Geol., $4(2-3)$, 111-117.

Hedlund, R. W. \& Norris, G. 1968. Spores and pollen grains from the Fredericksburgian (Albian) strata, Marshall County, Oklahoma. Pollen et Spores, 10 (1), 129-159.

Herngreen, G. F. W. 1973. Palynology of Albian to Cenomanian strata of borehole 1-QS-1-Ma, state of Maranhao, Brazil. Pollen et Spores, 15 (3-4), 515-555.

Herngreen, G. F. W. 1975. Palynology of Mid and Upper
Cretaceous strata in Brazil. Meded. R.G.D., n.s. 26 (3), $39-91$.

Herngreen, G. F. W. \& Chlonova, A. F. 1981. Cretaceous microfloral provinces. Pollen et Spores, 23 (3-4), 441-555.

Hickey, L. J. \& Doyle, J. A. 1977. Early Cretaceous fossil evidence for angiosperm evolution. Bot. Rev., 43 (1), 3-104.

Hochuli, P. A. \& Kelts, K. 1980. Palynology of Middle Cretaceous black clay facies from DSDP sites 417 and 418 of the Western North Atlantic. Initial Reports of the Deep Sea Drilling Project, 51-53: 897-955.

Hughes, N. F. 1976. Palaeobiology of angiosperm origins, 242 pp., Cambridge Univ. Press.

Hughes, N. F. 1986. The problems of data-handling for early angiosperm-like pollen. In Spicer, R. A. \& Thomas, B. A. (Eds.), Systematic and taxonomic approaches to palaeobotany. Systematics Association Series. no. 31, pp. 235-253.

Hughes, N. F., Drewry, G. E. \& Laing, J. F. 1979. Barremian earliest angiosperm pollen. Palaeontology, 22 (3), 515535.

Jardine, S. \& Magloire, L. 1965. Palynologie et stratigraphie du Cretace des basins du Senegal et de Cote d'Ivoire. Mem. Bur. Rech. Geol. Min., 32, Coll. Int. Micropal., 187-222.

Kotova, I. Z. 1978. Spores and pollen from Cretaceous deposits of the Eastern North Atlantic Ocean, DSDP Leg 41, sites 367 and 370. Initial Reports of the Deep Sea Drilling Project, Suppl. to vols. 38, 39, 40 and 41, 841-881.

Krutzsch, W. 1959. Einige neue Formgattungen und -arten von sporen und pollen aus der mitteleuropaischen Oberkreide und dem Tertiar. Palaeontographica, B, 105, 125-157.

Laing, J. F. 1975. Mid-Cretaceous angiosperm pollen from Southern England and Northern France. Palaeontology, 18 (4), 775-808.

Morgan, R. P. 1976. Albian-Senonian palynology of site 364, Angola Basin. Initial Reports of the Deep Sea Drilling Project, 40, 915-951.

Norris, G. 1967. Spores and pollen from the lower Colorado Group (Albian-Cenomanian) of Central Alberta. Palaeontographica B, 120, 72-115.

Penny, J. H. J. 1968a. An Early Cretaceous angiosperm pollen assemblage from Egypt. Spec. Publ. Palaeontology, 35, 121-134.

Penny, J. H. J. 1986b. Early Cretaceous angiosperm pollen from Egypt. Unpublished $\mathrm{PhD}$ thesis, University of Cambridge (222 pp., 33 pls.).

Penny, J. H. J. 1988. Early Cretaceous acolumellate semitectate pollen from Egypt. Palaeontology, 31(2), 373-418. $373-418$.

Playford, G. 1971. Palynology of Lower Cretaceous (Swan River) strata of Saskatchewan and Manitoba. Palaeontolo$g y, 14$ (4), 533-565.

Potonie, R. 1966. Synopsis der gattungen der sporae dispersae. IV Teil: nachtrage zu allen gruppen (turmae). Beih. Geol. Jb., 72.

Potonie, R. 1970. Synopsis der gattungen der sporae dispersae. V Teil: nachtrage zu allen gruppen (turmae). Beih. Geol. Jb., 87.

Regali, M. S. P., Uesugui, N. \& Santos, A. S. 1974. Palinologia dos sedimentos meso-cenozoicos do Brasil ( 1 \& 2). Bol. Tec. Petrobras, 17, 177-191 and 263-301.

Rouse, G. E. 1962. Plant microfossils from the Burrard Formation of Western British Columbia. Micropalaeontology, 8 (2), 187-218. 
Schrank, E. 1982. Kretazische pollen und sporen aus dem "Nubischen Sandstein" des Dakhla-Beckens (Agypten). Berliner Geowiss Abh. (A), 40, 87-109.

Schrank, E. 1983. Scanning electron and light microscopic investigations of angiosperm pollen from the Lower Cretaceous of Egypt. Pollen et Spores, 25 (2), 213-242.

Singh, C. 1971. Lower Cretaceous microfloras of the Peace River area, Northwestern Alberta, (2 vols and appendix). Res. Counc. Alberta Bull., 28, 1-299 and 301-542.

Srivastava, S. K. 1975. Microspores from the Fredericksburg group (Albian) of the Southern United States. Paleobiol continentale, 6, 1-119.

Thusu, B. \& Eem, J. G. L. A. van der 1985. Early Cretaceous (Neocomian-Cenomanian) palynomorphs. $J$. Micropaleontol, 4 (1), spec. vol. The palynostratigraphy of North-East Libya, 131-150, pls. 53-60. 